tions and career tracks for junior staff, job security and tenure, part-time and fixed-term academic staff, academic pay scales, flexible and performance-related income streams, declining academic salaries, human resource development and academic training, teaching standards, and work and teaching loads.

Many measures have been taken to preserve or enhance the quality of teaching and learning and of research and service under conditions of tighter financial control and to reverse rising student-staff ratios. They include restructuring the higher education system to set different quality objectives and distributing resources for various sectors, institutions, or subunits in higher education; improving the training of academic staff by reorganizing junior academic careers and career criteria; enhancing the assessment and evaluation of academic staff performance and linking them to rewards and sanctions; and redesigning the management of higher education institutions and increasing the ability to steer academic staff. Thus even in higher education we can identify methods used by other kinds of manufacturing or service companies to improve quantity or quality of output without additional resources or staff.

The obvious and serious danger of this approach is that it could threaten the core elements of the academic profession - that is, collegial decision making, autonomy in teaching and research, intellectual leadership and social prestige, and the certainty of economic and intrinsic rewards. There is some evidence that might bear out the theory of the deprofessionalization of academics: salaries are being broken into different components and seem to be on the decline; academic tenure has become an issue in many countries; teaching and research are monitored and inspected; and a casual workforce of part-time and fixed-term staff is growing at the periphery of the professional core. Last, but not least, in some continental European countries we see a change in the status of academics from that of civil servant to a more contractual relationship. This thesis, however, tends to take as reality the new rhetoric of output-based orientation, consumerism, market-driven flexibility, and managerialism. It tends to overestimate the impact of external actors and conditions on the life of higher education while underestimating dissimilar elements in specific national contexts, as well as the adaptability, inertia, resistance, and variety of responses of academics.

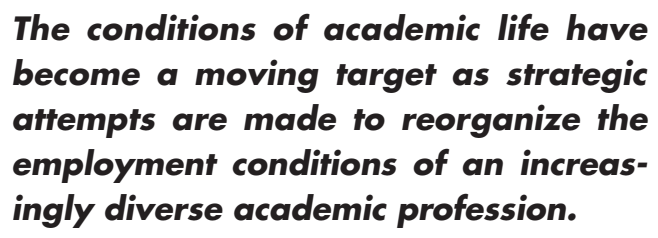

The aforementioned study is finding that, despite claims of a general erosion in academic employment and working conditions, evidence of such a trend is not as strong, consistent, or universal as previously believed.

\section{In Search of a New Academic Professionalism}

Having said this, one cannot overlook the fact that the academic profession now finds itself in a rather defensive position. For a long time, academics successfully accommodated changing environments to their aims and needs. Now, however, they are increasingly blamed for higher education's shortcomings and problems in defining a new place in the emerging knowledge society. It is therefore important that academics find a third way beyond erosion and traditionalism and seek strategies of active involvement in the ongoing process of change. So far, the traditional character of the academic profession has not been affected by the advocacy of a new model. It has, rather, been left to the ongoing process of change to create a new professionalism of the academic profession and various subprofessions.

\title{
Overreliance on Part-Time Faculty: An American Trend
}

\section{Ernst Benjamin}

Ernst Benjamin is associate general secretary and director of research of the American Association of University Professors in Washington, D.C. Address: 1012 14th St. NW, Washington, D.C. 20005.

$\mathrm{T}$ he proportion of faculty who teach part time on American campuses has nearly doubled in the last 30 years. In 1970, only 22 percent of faculty held parttime appointments; today, at least 42 percent teach part time-more than twice the proportion of part-time workers in the overall U.S. labor force. This shift is one of the most controversial trends in American higher education.
Proponents of hiring part-time faculty assert that most are happy with their jobs and that institutions are better able to reduce costs and adjust to enrollment variations. Moreover, many part-time faculty are able instructors who focus more on teaching students than on conducting research. Critics say part-time faculty are underpaid and lack the medical insurance essential in the American system of health care. They note with concern that women, who hold just over one-third of full-time appointments, hold nearly half of part-time appointments. They argue that many parttime faculty are inadequately qualified, less productive, superficially evaluated, carelessly hired, and too easily reappointed. Finally, as part-time faculty displace full- 
time faculty, fewer full-time faculty are available to work with students outside class. The data show that both proponents and critics are right in some respects.

\section{The proportion of faculty who teach part time on American campuses has nearly doubled in the last 30 years.}

\section{Variation by Institution, Level, and Program}

The use of part-time faculty varies greatly by type of institution. Whereas nearly two-thirds of community college faculty members teach part time, less than one-third of faculty in four-year institutions hold part-time appointments. The greater reliance on part-time faculty in two-year institutions partly explains the higher numbers of part-time faculty in the United States, compared to university systems elsewhere. When, however, graduate assistants are included, the proportion of full-time faculty members even in four-year institutions drops to less than half. Because part-time faculty members teach relatively more class hours per faculty member in four-year institutions, the 48 percent of part-time staff at four-year schools probably teach at least 40 percent of the classes and more than half the classes in the first two years of instruction.

Although primarily associated with lower-division instruction, part-time teaching is important to upperdivision and graduate instruction, especially in vocational or professional programs. The disciplines in which 40 percent or more of the appointments at four-year institutions are part time include law, communications, health sciences, teacher education, and business. In the liberal arts, only English relies on more than 40 percent part-time faculty appointments. Of course, part-time liberal arts faculty and graduate assistants teach more students in more classes; consequently, lower-division liberal arts classes account for the majority of part-time staff.

Those who teach part time are as likely as their fulltime counterparts to have earned academic achievement awards as undergraduates, but their graduate preparation varies significantly. At four-year institutions, 75 percent of full-time faculty - but only 36 percent of part-time facultyhave terminal degrees. Full-time faculty selection usually follows a national search, a campus visit, and a review by prospective colleagues and administrators. Performance evaluation is recurrent, demanding, and often includes national as well as local assessment. Selection and evaluation of part-time faculty lack these procedures and is often haphazard. Moreover, though it is easier to replace an ineffective part-time instructor, the procedures do not assure that the replacement will be an improvement.

\section{Conditions and Costs}

The conditions of part-time appointment diminish productivity and effectiveness. Part-time faculty members are seldom paid for such activities as course preparation, office hours, grading, or committee work At research universities, where full-time faculty members spend more than two hours outside class on instruction-related activities for every hour in class, the part-time faculty ratio is one hour outside class to one hour inside. At community colleges, full-time faculty members spend about 48 minutes outside class on teaching-related activities for each hour they spend in class. For part-time community college faculty members, the time drops to only about 12 minutes outside class per in-class hour. Part-time faculty members publish less than full-time faculty, except in community colleges, where there is little research in general due to the heavy teaching loads of full-time faculty. Variations in research activity may be consistent with institutional mission, but declines in the proportion of time devoted to out-ofclassroom instructional activities are not.

Part-time appointments are less expensive. With payment typically ranging from $\$ 1,000$ to $\$ 3,000$ per course, institutions can reduce per-unit instructional cost by onehalf to two-thirds. But buying cheap is not always economical. Reliance on part-time faculty is greatest in lower-division liberal arts programs, where students are most in need of faculty support and are least likely to find it.

\section{The conditions of part-time appointment diminish productivity and effectiveness.}

Employment conditions for part-time faculty vary greatly by field of instruction. Part-time liberal arts faculty more often than part-time vocational faculty, lack other part- or full-time employment and, therefore, tend to be less satisfied. Their average income is two-thirds that of vocational instructors in community colleges and 55 percent of average salaries at four-year institutions. Liberal arts parttime faculty in general-nearly two-thirds of these women-report they would prefer but cannot find full-time academic appointments. These differences help explain why proponents and critics of hiring part-time faculty often talk past one another. Satisfied part-time instructors, whose outside jobs often contribute to their instructional effectiveness, more often teach in vocational programs. Dissatisfied faculty, who lack time and opportunity to maintain their professional skills, more often teach in lowerdivision liberal arts programs.

Policymakers commonly attribute shortcomings in faculty-student involvement to declines in full-time faculty 
teaching loads rather than to increased reliance on parttimers. This thinking ignores two facts. First, instructional hours vary with institutional mission. Faculty members spend more hours in class at two-year and bachelor's-degree-granting institutions than at comprehensive or research universities. Second, as teaching loads increase, out-of-class instructional time diminishes. Improving the quality of instruction requires that institutions that have relied excessively on inadequately supported part-time appointments increase their proportion of full-time appointments and improve the support for and quality of their part-time appointees.

\section{Academic Freedom in Hong Kong-Threats Inside and Out}

\section{Philip G. Altbach}

Philip G. Altbach is Monan professor of higher education and director of the Center for International Higher Education at Boston College. He has been Onwell Fellow in the Faculty of Education at Hong Kong University

$I^{2}$ n early July, academic freedom became front-page news in Hong Kong when Professor Robert Chung of Hong Kong University, a prominent pollster, accused the university's vice chancellor of pressuring him to stop conducting public opinion polls concerning the territory's chief executive. A special commission has been appointed to look into the charges and into academic freedom generally, and Hong Kong's academics, insecure following the accession to China in 1997, are feeling even more unhappy.

It may be useful to look at this crisis from an international perspective, since many of the issues facing Hong Kong's universities are common elsewhere. Hong Kong is in an unusual position. It is precariously balanced between the norms and values of the international academic community, where academic freedom is a central conviction, and the complex reality of its special "one country, two systems" status as a part of China. China has no commitment to academic freedom, and many in Hong Kong see Chinese political and cultural norms as gradually taking over.

\section{Colonial Influences}

Hong Kong University has its roots as a colonial institution. Established in 1911 by the British, its structures and values were from the beginning British. Until relatively recently, academic power was in the hands of expatriate senior professors. British authorities, especially in the latter period of colonial rule, permitted the university academic freedom and considerable autonomy, but the institution looked to Britain rather than to Hong Kong, or to Asia, for guidance. Even today, there is a complex relationship between the university and Hong Kong society.

Hong Kong academics are especially attuned to violations of academic freedom precisely because of their special political and societal circumstances. It is admirable that the academic community remains committed to the core values of the university. These very circumstances may, however, obscure other realities affecting higher education in Hong Kong-and worldwide.

\section{Trends Affecting Higher Education}

Many trends threaten not only the traditional values of academe, but may also be problematical for academic freedom. It is useful to discuss some of them, if only to show that Hong Kong is not the only place where the ideals of the university are in jeopardy.

\section{Managerialism}

Worldwide, the traditional control of the central elements of the university by the faculty is being diminished. In the name of efficiency and accountability, business practices imported from the corporate sector are coming to dominate the universities. Governance, the traditional term used to describe the uniquely participatory way that universities work, is being replaced by management. The academic staff has had essential responsibility for the curriculum, the admission of students and the award of degrees, and the hiring and promotion of professors, and usually dominated the decision-making bodies of the university. Increasingly, managers are taking control of the levers of power. This does not make the professors happy and may, in the long run, create academic institutions that have no core academic values.

\section{Accountability and Autonomy}

Simply stated, traditional autonomy - the ability of the professoriate to control the classroom, the curriculum, and the overall conditions of academic work-is being severely constrained by accountability - the idea that those paying the costs of higher education should have the right to determine how funds should be spent. This often extends to research-professors once were able to determine their own research priorities and often to obtain funding for them. Now, funds are increasingly allocated by corporations that demand specific results. This creates problems not only for the future of basic research (which does not yield immediately usable products) but for the academic freedom to pursue research topics.

\section{Diminishing Power}

The academic profession is, simply put, losing its once dominating power over the university. Managers are making 